\title{
Herbicide concentrations in waterways following aerial application in a steepland planted forest in New Zealand
}

Brenda R. Baillie

\begin{abstract}
Background: The use of herbicides to control competing vegetation in planted forests is an important component of forest management. The increasing public aversion to herbicide use includes the possible contamination of receiving aquatic environments. The risk of surface run-off, leaching and erosion processes transporting herbicide residues to waterways, is potentially higher in steepland forests containing soils with high leaching potential. The purpose of this study was to measure the concentrations of terbuthylazine and hexazinone, two herbicides commonly used in post-plant weed control in New Zealand, in waterways, when aerially applied in a steepland forest catchment with Recent Soils.
\end{abstract}

Methods: Terbuthylazine and hexazinone were applied, at 6 and $1.5 \mathrm{~kg} \mathrm{ha}^{-1}$, respectively, to 30 ha distributed over a 193-ha catchment. Herbicide concentrations were measured in stream water and sediment in a 12-ha headwater sub-catchment (W1) (57 \% sprayed) and in stream water at two sites further down the catchment. These sites were monitored prior to, and for 5 months after, herbicide application.

Results: The highest concentrations in stream water were recorded on the day of herbicide application at W1 (terbuthylazine, $9.6 \mathrm{\mu g} \mathrm{L}^{-1}$; hexazinone, $5.3 \mu \mathrm{g} \mathrm{L}{ }^{-1}$ ). Terbuthylazine concentrations were above drinking water standards for several hours, well below the decadal time frame required to exceed these standards. Thereafter, concentrations rapidly declined, with the highest concentrations recorded 1 month after herbicide application, 2 days after a $50-\mathrm{mm}\left(24 \mathrm{~h}\right.$ ) rainfall event. Concentrations declined downstream and were $<5 \mu \mathrm{g} \mathrm{L}^{-1}$ where the stream exited the forested catchment. Terbuthylazine only was detected in sediment for up to 60 days after herbicide application. Concentrations and persistence of both herbicides in stream water were well below toxic levels for aquatic organisms.

Conclusions: The potential risks to aquatic environments from herbicide application in steepland conditions were partially mitigated by the 30-m 'no-spray' zone along the stream margins, along with logging slash in the stream channel and the spatial distribution of the treated areas within the catchment. Under these operational conditions, and when applied according to manufacturer's instructions, the downstream risks to human health and aquatic environments appeared to be low.

Keywords: Herbicide, Terbuthylazine, Hexazinone, Planted forest, New Zealand, Water quality, Aerial application

Correspondence: brenda.baillie@scionresearch.com

Scion, Private Bag 3020, Rotorua 3046, New Zealand 


\section{Background}

Vegetation management is critical for optimising timber and fibre production and maintaining the economic viability of managed forests (McCarthy et al., 2011; Rolando et al., 2013; Wagner et al., 2006). Herbicides play an integral role in the management of competitive vegetation in these forests, particularly during the establishment phase of the forestry cycle. However, there is increasing global pressure to reduce or eliminate herbicides, driven by factors such as increasing public aversion to herbicide use in forests, forest certification requirements and governmental regulations restricting or prohibiting herbicide use (Forest Stewardship Council, 2005; Shepard et al., 2004; Thiffault and Roy 2011; Wagner et al., 1998). Contamination of groundwater and surface water resources from pesticides are an emerging issue (Baillie \& Neary 2015), contributing to the degradation of water quality in many parts of the world (Barbash and Resk 1996; Larson et al., 1997; Vörösmarty et al., 2010). Herbicides are the most common pesticide detected in New Zealand's surface water and groundwater. Both terbuthylazine and hexazinone have been detected in surface waters, and terbuthylazine is the most common herbicide detected in groundwater, although concentrations are currently low $\left(<1 \mu \mathrm{g} \mathrm{L}^{-1}\right)$ or below drinking water standards (Close \& Skinner 2012; Tulagi 2014).

Non-chemical methods of vegetation control such as prescribed fire, manual and mechanical site preparation, manipulation of tree density and shading, establishment of cover plants to suppress weed growth and biological control offer alternative options to herbicide use. To date, mechanical weed control remains the most common non-chemical alternate to herbicides, particularly in Europe (McCarthy et al., 2011) and Québec (Canada) where herbicides are banned on Crown forest lands (Thiffault and Roy 2011). However, mitigating factors such as higher costs, lower efficiency, limited labour resources and environmental risks associated with these options mean that herbicides continue to be used in varying degrees for controlling competing vegetation in managed forests (Little et al., 2006; McCarthy et al., 2011; Neary and Michael 1996; Rolando et al., 2013), particularly in countries, such as New Zealand, where maximising timber and fibre production is the primary goal (Wagner et al., 2006).

Planted forests occupied around 1.7 million hectares of New Zealand in 2012, which are predominantly planted in Pinus radiata D.Don (Forest Owners Association \& Ministry for Primary Industries, 2013). Herbicides are an important component of planted forest management in New Zealand (e.g. Richardson, 1993; Rolando et al., 2013; Tran et al. 2015). They are widely used during the establishment phase of the forestry cycle for weed control prior to and during the first few years after tree planting. Glyphosate ( $N$-(phosphonomethyl)glycine) is the main herbicide used in New Zealand's planted forests prior to planting, with terbuthylazine (N2-tert-butyl-6chloro-N4-ethyl-1,3,5-triazine-2,4-diamine) and hexazinone (3-cyclohexyl-6-dimethylamino-1-methyl-1,3,5-triazine-2,4-(1H,3H)-dione) the main herbicides applied, usually in combination, for post-plant weed control. The application method varies among regions depending on weed composition, soil type, terrain and sensitivity of adjoining areas. Overall, around $60 \%$ of the treated area is directly spot sprayed with herbicides, with herbicides being aerially applied to the remaining $40 \%$ (Rolando et al., 2013).

Initial research on the environmental fate of herbicides used in New Zealand's planted forests focused on the aerial application of terbuthylazine and hexazinone for post-plant weed control (Baillie et al., 2015; Garrett et al., 2015). Both terbuthylazine and hexazinone belong to the triazine group of herbicides and are designed to control a broad range of grasses, broad-leaved weeds and woody plants (University of Hertfordshire, 2015). Terbuthylazine is rated slightly hazardous (class III) while hexazinone is considered moderately hazardous (class II) under the World Health Organization classification of pesticides (World Health Organization, 2010).

The water solubility and hence leaching potential of terbuthylazine is low (Table 1), but its potential to adsorb to soil and organic matter is high (Watt et al., 2010), indicating that transport via sediment and organic matter in waterways is likely (Kronvang et al., 2003). In

Table 1 Freshwater environmental and toxicology data for hexazinone and terbuthylazine (MacBean 2012; Ministry of Health, 2008; University of Hertfordshire, 2015; World Health Organization, 2011). Updated from Table 1 in Baillie et al. (2015)

\begin{tabular}{|c|c|c|c|c|c|c|c|c|c|}
\hline \multirow[t]{2}{*}{ Herbicide } & Water solubility & $\begin{array}{l}\text { Half-life in } \\
\text { water }\left(\mathrm{DT}_{50}\right)\end{array}$ & $\mathrm{EC}_{50}^{\mathrm{a}}$ algae & $\begin{array}{l}\mathrm{LC}_{50}^{\mathrm{b}}(48 \mathrm{~h}) \\
\text { Daphnia }\end{array}$ & $\begin{array}{l}\mathrm{LC}_{50}(96 \mathrm{~h}) \\
\text { rainbow trout }\end{array}$ & $K_{\text {ow }}^{c} \log$ & $B C F^{d}$ & $\begin{array}{l}\text { DWS New } \\
\text { Zealand }\end{array}$ & DWS WHO \\
\hline & $\mathrm{mg} \mathrm{L}^{-1}$ & days & $\mu g L^{-1}$ & $\mu g L^{-1}$ & $\mu g L^{-1}$ & & & $\mu g L^{-1}$ & $\mu g L^{-1}$ \\
\hline Terbuthylazine & 9 & $33-73$ & 16 & $>69,300$ & 220 & 3.4 & 34 & 8 & 7 \\
\hline Hexazinone & 29,800 & 56 & $7-210$ & 152,000 & $>320,000$ & 1.2 & 7 & 400 & - \\
\hline
\end{tabular}

${ }^{\mathrm{a}} \mathrm{EC}_{50}$ is the median effective concentration for a specified time: $72 \mathrm{~h}$ for terbuthylazine and $120 \mathrm{~h}$ for hexazinone

${ }^{\mathrm{b}} \mathrm{LC}_{50}$ (lethal concentration) is the concentration in water that kills $50 \%$ of the test organisms

${ }^{c} K_{\text {ow }}$ (octanol/water partition coefficient) is the ratio of the concentration of a chemical in octanol and in water at equilibrium

${ }^{\mathrm{d}} B C F$ bioaccumulation factor

${ }^{\mathrm{e}} \mathrm{DWS}$ drinking water standards 
the aquatic environment, terbuthylazine is most toxic to aquatic plants, followed by fish and aquatic invertebrates (Table 1) (University of Hertfordshire, 2015). When assessing bioaccumulation risk, an octanol/water partition coefficient $\left(\log K_{\mathrm{ow}}\right)$ of $\geq 3$ is a common international trigger point of concern while a bioaccumulation factor $(\mathrm{BCF})$ (the ratio of the concentration of a chemical in an organism compared with that in water) of $<100$ is considered a low risk (Beek et al., 2000). Thus, the perceived risk may depend on the assessment system used. In the case of terbuthylazine, there is potential risk for this herbicide to bioaccumulate in the environment based on the $\log K_{\text {ow }}$ value whereas the bioaccumulation risk is low based on the BCF (Table 1). Hexazinone is highly soluble in water (Table 1), increasing the potential risk of surface run-off and leaching into waterways. Similar to terbuthylazine, hexazinone is toxic to aquatic plants but it is of lower toxicity to aquatic invertebrates and fish (Table 1). Given its high water solubility, the potential of hexazinone to bioaccumulate is low as indicated by its BCF factor of 7 (Table 1).

An earlier study assessing the environmental fate of aerially applied terbuthylazine and hexazinone was conducted on Pumice Soil in the Bay of Plenty region of New Zealand (Baillie et al., 2015; Garrett et al., 2015). Pumice Soil was selected due to its low adsorption capacity making it a soil type potentially at risk to off-site movement of herbicides (Watt et al., 2010). The results of this study indicated low leaching potential to waterways for both terbuthylazine and hexazinone when applied according to current operational standards (Garrett et al., 2015). Similar to studies elsewhere (McBroom et al., 2013; Miller and Bace 1980; Neary et al., 1983), herbicide concentrations in the stream network were highest on the day of herbicide application and during rainfall events shortly after application (Baillie et al., 2015).

Steepland forests are considered to be at high risk of off-site movement of herbicides into waterways via leaching, run-off and sediment transport, due to the steep, erodible soils and susceptibility to erosion during high rainfall events (Baillie \& Rolando, 2015; Lavy et al., 1989). Of the 1.7 million hectares of planted forest in New Zealand (Forest Owners Association \& Ministry for Primary Industries, 2013), around $20 \%$ are on steep terrain $\left(>20^{\circ}\right)$ (Dunningham et al., 2012). The objective of the trial reported here was to extend the current research on the aquatic fate of terbuthylazine and hexazinone in New Zealand's planted forests into a region of differing geological and hydrological conditions. This was achieved by assessing the risk of these two herbicides to the aquatic environment when aerially applied within a steepland planted forest catchment. Specifically, the trial was implemented on a Recent Soil, identified as one of the most vulnerable soil orders with respect to leaching potential due to low soil organic carbon and relatively high pH (Watt et al., 2010).

\section{Methods}

\section{Study site}

The study area was located in a planted forest in the eastern Bay of Plenty region of New Zealand (Fig. 1). The catchment is in steep $\left(26^{\circ}-35^{\circ}\right)$ greywacke hill country overlain by Typic Tephric Recent Soils (Garrett et al., 2016; Hewitt, 1998; Ministry of Works and Development, 1975). The mean annual rainfall was $1504 \mathrm{~mm}$, and the mean annual temperature was $12.9{ }^{\circ} \mathrm{C}$ (NIWA

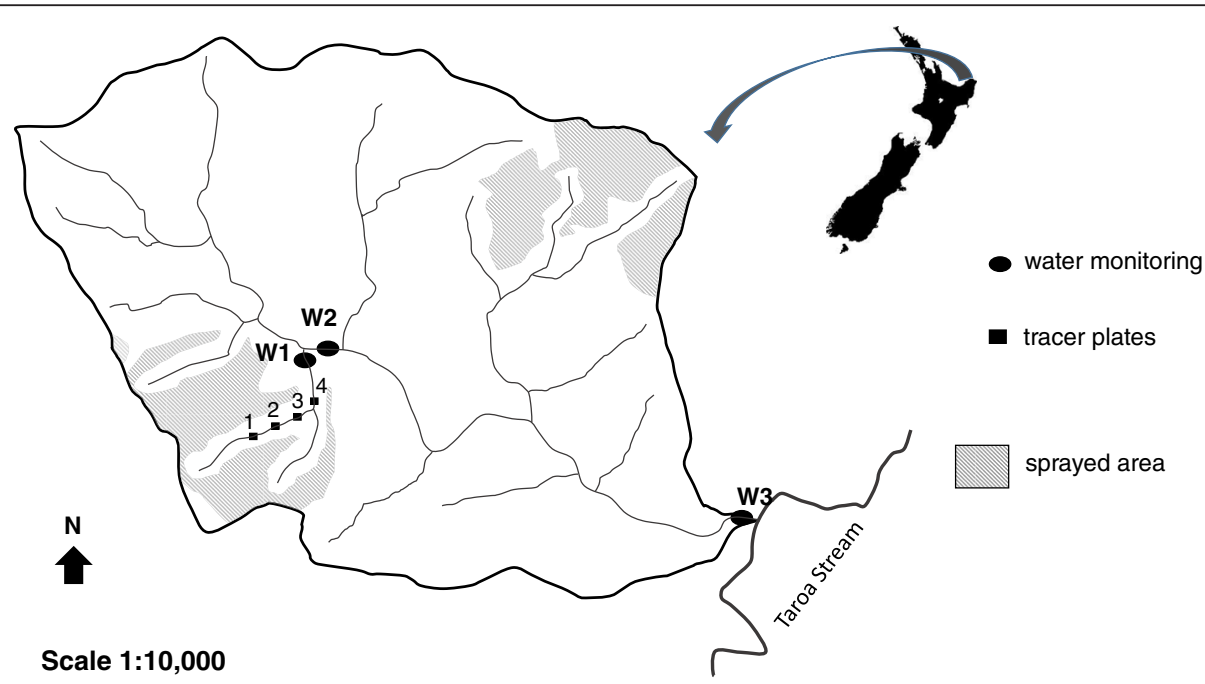

Fig. 1 Location of the trial catchment in the eastern Bay of Plenty, New Zealand, showing the areas aerially treated with terbuthylazine and hexazinone, the location of the four sets of tracer plates (1-4) and the location of the three water-monitoring points (W1, W2 and W3) within the stream network 
2012). The eastern Bay of Plenty can experience periods of widespread and heavy rainfall and high winds, usually in association with north-west to north-east airflows or occasional tropical cyclones (Chappell, 2013). The stream network in the trial catchment drains into the Taroa Stream (Fig. 1), a tributary of the Haparapara River. Water monitoring was established at three points along the stream network within the trial catchment (Fig. 1) to capture the spatial extent of the areas sprayed within the catchment (Fig. 1) and to assess changes in herbicide concentrations along the stream continuum during and after herbicide application. Vegetation cover in the catchment was comprised of young ( $\leq 2$-year-old) second-rotation and mature (28-29-year-old) firstrotation $P$. radiata (Table 2 ). All herbicide application was in the areas of 1-year-old $P$. radiata.

\section{Herbicide treatment}

The trial catchment was aerially sprayed on 10 November 2014 with AGPRO Valzine Extra (AGPRO NZ Ltd, Auckland) containing $400 \mathrm{~g} \mathrm{~L}^{-1}$ of terbuthylazine and $100 \mathrm{~g} \mathrm{~L}^{-1}$ of hexazinone in the form of a suspension concentrate, applied at the rate of $15 \mathrm{~L} \mathrm{ha}^{-1}\left(6 \mathrm{~kg} \mathrm{ha}^{-1}\right.$ of terbuthylazine and $1.5 \mathrm{~kg} \mathrm{ha}{ }^{-1}$ hexazinone). These application rates are typical for this type of operation in New Zealand's planted forests (Rolando et al., 2013). Tartrazine, a colourimetric tracer used to measure spray deposition (Pergher, 2001; Richardson et al., 1989), was added to the herbicide solution at the rate of $0.0042 \mathrm{~kg} \mathrm{~L}^{-1}$. The herbicide solution was applied by a Robinson R44 Raven II helicopter using a 12-m-long spray boom fitted with 0.047-24 tube ACCU-FLO ${ }^{\text {ta }}$ radial nozzles (Bishop Equipment Mfg. Inc., PA, USA) that delivered 1400-1500- $\mu \mathrm{m}$ (volume mean diameter) droplets. The swath width was $9 \mathrm{~m}$ using a half-overlap spray pattern. The flight direction was predominantly at right angles to the stream for most of the sprayed area. On occasion, flight lines were parallel to the stream, with a release height above ground of 12-21 m (40-70 ft). Under the Bay of Plenty Regional Air Plan, discharge of agrichemical chemicals from an aircraft must not result in any harmful concentration of agrichemicals into water (Bay of Plenty Regional Council, 2003). In this catchment, a no-spray boundary of approximately $30 \mathrm{~m}$ was maintained around the stream margins (Fig. 1). In total, $42 \mathrm{~kg}$ of terbuthylazine and $10.5 \mathrm{~kg}$ of hexazinone were applied to the land upstream of water-monitoring point 1 (W1), Fig. 1.

\section{Data collection}

A meteorological station (Campbell Scientific Inc., UT, USA) was established at the top of the catchment upstream from W1 on 25 September 2014 to record air temperature $\left({ }^{\circ} \mathrm{C}\right)$, relative humidity $(\%)$, wind direction (degrees) and speed $\left(\mathrm{m} \mathrm{s}^{-1}\right)$ and rainfall $(\mathrm{mm})$ at $15-\mathrm{min}$ intervals for the duration of the trial, which ended on 13 April 2015.

On the day of herbicide application, four sets (labelled 1-4) of 10 tracer plates (stainless steel plates $76 \times$ $152 \mathrm{~mm}$ ) were spaced out along a 250-m section of stream channel, upstream of water-monitoring point 1 (W1) (Fig. 1), to measure any spray deposition reaching the stream channel. Within each set, the 10 tracer plates were positioned $1 \mathrm{~m}$ apart along the stream channel. The plates were positioned horizontally on top of the logging slash as most of the stream channel upstream from W1 was covered in logging slash (residue branches, twigs and needles from harvesting operations). After herbicide application, each tracer plate was collected and placed in a separate sealable plastic bag for transport to the laboratory for analysis.

To assess herbicide concentrations in the downstream receiving environment, a more intensive water and sediment sampling regime was established at watermonitoring point 1 (W1), which covered the highest proportion of the catchment sprayed (Table 1). Water only was monitored at the two downstream sites (W2 and W3) to determine the downstream dilution effect on herbicide concentrations. Point W2 was located approximately $100 \mathrm{~m}$ downstream of $\mathrm{W} 1$, and $\mathrm{W} 3$ was a further $1.43 \mathrm{~km}$ downstream of W2, just above the confluence with the Taroa Stream (Fig. 1). Water samples $(500 \mathrm{~mL})$ for herbicide analysis were taken twice prior to spraying at W1 and W2 and on a single occasion at W3, commencing on 23 October 2014.

Table 2 Characteristics of the trial catchment ${ }^{a}$

\begin{tabular}{llllllll}
\hline Site & $\begin{array}{l}\text { Catchment } \\
\text { area (ha) }\end{array}$ & $\begin{array}{l}\text { Area (ha) } \\
\text { sprayed }\end{array}$ & $\begin{array}{l}\text { Catchment area } \\
\text { sprayed (\%) }\end{array}$ & $\begin{array}{l}\text { Unplanted } \\
\text { (ha) }\end{array}$ & $\begin{array}{l}<1 \text {-year-old } \\
\text { P. radiata (ha) }\end{array}$ & $\begin{array}{l}\text { 1-2-year-old } \\
\text { P. radiata (ha) }\end{array}$ & $\begin{array}{l}\text { 28-29-year-old } \\
\text { P. radiata (ha) }\end{array}$ \\
\hline W1 $^{c}$ & 12 & 7 & 57 & 0 & 11 & 0 & 1 \\
W2 & 62 & 12 & 19 & 10 & 18 & 18 & 15 \\
W3 & 193 & 30 & 16 & 68 & 43 & 32 & 50 \\
\hline
\end{tabular}

${ }^{a}$ Data provided by forest company GIS and forest information databases

${ }^{b}$ All herbicide application was in the areas of <1-year-old P. radiata. NB: Because of the 30-m 'no-spray' zone along the stream margins (Fig. 1), the area of 1-year-old pine sprayed with herbicides is less than the total area

${ }^{c} W$ water-monitoring point 
On the day of herbicide application (10 November 2014), single 500-mL water samples for herbicide analysis were taken at W1, at 15-min intervals during the first hour of monitoring, starting as soon as spraying was completed in the vicinity of W1. Smaller $(125 \mathrm{~mL})$ samples were then taken at 15-min intervals for the next $4 \mathrm{~h}$. Four consecutive samples were combined to produce composite hourly water samples. At both W2 and W3, a single water sample for herbicide analysis was taken during the 5-h period of monitoring at W1. Following the day of herbicide application, water samples for herbicide analysis were collected from all three sites (W1-W3) at 1, 2, 7, 30, 34, 59, 94 and 154 days after the herbicide treatment (DAT), with the exception of day 2 for W3, ending on 13 April 2015. The logistical and safety issues in relation to the remoteness and steepness of the site limited the ability to monitor rainfall events occurring after herbicide application. There was insufficient sediment in the stream channel at W1 for sampling prior to herbicide application. Sediment samples were taken at W1 at 1, 30, 59, 94 and 154 DAT for herbicide analysis. Additional water samples for water quality analysis were taken at all three sites on all the sampling dates above, except for the first two days after treatment (Table 3). All water and sediment samples were labelled and stored in chilled containers for transportation to the laboratory, accompanied by a chain-ofcustody form. Flow measurements were taken at all three sites on all sampling dates using a Hach FH950 portable velocity meter (Hach, Loveland, CO, USA).

\section{Laboratory procedures}

Spray deposits were washed off the tracer plates with a known quantity of water. The light absorbance of the tracer plate samples was determined using colourimetric analysis at a light absorbance of $427 \mathrm{~nm}$ on a T70 spectrophometer (PG Instruments, UK) and compared with the light absorbance from a set of reference samples with known dye concentrations. From this, the actual amount of dye in the sample and thus the herbicide concentration in each sample was calculated (Richardson et al., 1989). The average concentration for each set of 10 plates was used to calculate the percentage of the full application rate that reached the stream channel.

The water and sediment samples collected for herbicide analysis were analysed for hexazinone, terbuthylazine and terbuthylazine-desethyl (a metabolite of terbuthylazine) by an external laboratory (RJ Hill Laboratories, Hamilton, New Zealand; http:// www.hill-laboratories.com/) using in-house methods based on those of Roos et al. (1987) that are detailed in Baillie et al. (2015). Detection limits for hexazinone, terbuthylazine and terbuthylazine-desethyl in water ranged from 0.02 to $0.10 \mu \mathrm{g} \mathrm{L}^{-1}$. Detection limits for the same three compounds in sediment ranged from 7 to $12 \mu \mathrm{g} \mathrm{kg}^{-1}$ for hexazinone and terbuthylazine and 13 to $30 \mu \mathrm{g} \mathrm{L}^{-1}$ for terbuthylazinedesethyl. The stream-water samples collected for water quality were also analysed by RJ Hill Laboratories for $\mathrm{pH}$, electrical conductivity, total suspended solids (TSS) and dissolved organic carbon (DOC), following the methods of APHA 4500- $\mathrm{H}+$, APHA 2510 B, APHA 2540 D and APHA 5310 C (modified), respectively (APHA, 2012).

\section{Results \\ Weather conditions}

On the day of herbicide application, the weather conditions were within the forest company's prescribed limits for aerial herbicide application, with air temperature below $20{ }^{\circ} \mathrm{C}$, relative humidity $>55 \%$, maximum wind speed $<12 \mathrm{~km} \mathrm{~h}^{-1}$ and no rainfall. A total of $586 \mathrm{~mm}$ of rainfall was recorded for the duration of the trial with the highest 24-h rainfall event $(50.2 \mathrm{~mm})$ recorded on 12 December 2015 (32 DAT) (Fig. 2).

\section{Water quality and flow}

The $\mathrm{pH}$ was circumneutral at all three sampling sites for the duration of the trial (Table 3). Mean concentrations of TSS and DOC showed a decline down the stream system. The highest concentrations of TSS and DOC at W1 and W2 were recorded at the last sample date, 154 DAT, influenced by the preceding rainfall in the catchment. The wetted width of the stream channel averaged 0.4, 0.9 and $2.2 \mathrm{~m}$, and mean depths averaged $0.08,0.09$ and $0.04 \mathrm{~m}$ for W1, W2 and W3, respectively. Water flow showed less variation in the upper catchment at W1 and W2 at the time of water sampling compared with W3 at the base of the catchment (Fig. 3). Water flow was lowest in December (30 DAT) and February (94 DAT), coinciding with periods of preceding low rainfall.

Table 3 Water quality characteristics of the three monitoring sites, average (range)

\begin{tabular}{lllll}
\hline Site (sample size) & $\mathrm{pH}$ & $\begin{array}{l}\text { Electrical conductivity } \\
\mathrm{mS} \mathrm{m}^{-1}\end{array}$ & $\begin{array}{l}\text { Total suspended solids (TSS) } \\
\mathrm{g} \mathrm{m}^{-3}\end{array}$ & $\begin{array}{l}\text { Dissolved organic carbon (DOC) } \\
\mathrm{g} \mathrm{m}^{-3}\end{array}$ \\
\hline W1 $(n=9)$ & $7.1(6.8-7.4)$ & $9.8(9.3-10.5)$ & $9.2(4.0-21.0)$ & $5.2(1.6-19.4)$ \\
W2 $(n=9)$ & $7.2(7.0-7.3)$ & $8.8(8.0-9.7)$ & $7.2(1.5-27.0)$ & $3.5(1.4-11.0)$ \\
W3 $(n=8)$ & $7.2(6.9-7.4)$ & $9.4(8.9-10.4)$ & $3.7(1.5-12.0)$ & $2.0(1.3-3.8)$ \\
\hline
\end{tabular}




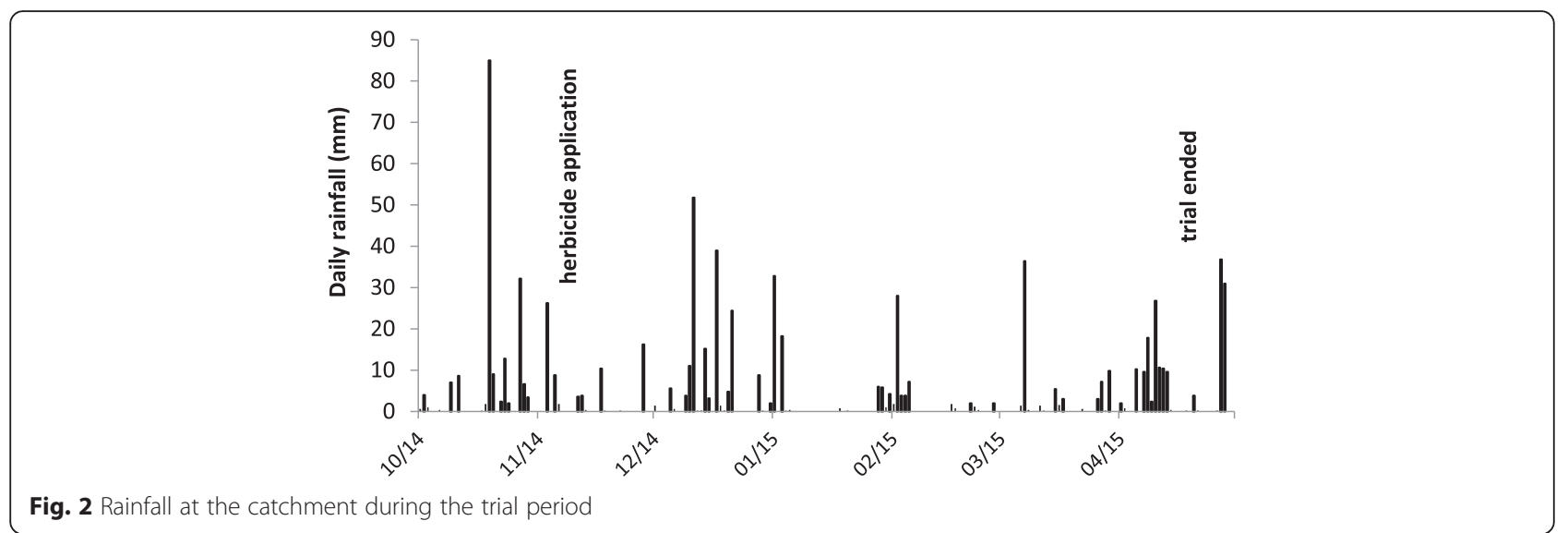

\section{Herbicide concentrations in water and sediment}

The analysis of the tracer plates showed that the percentage of the full application rate that reached the stream channel upstream of W1 on the day of herbicide application averaged 27, 10, 0.6 and $0.4 \%$ (sets 1-4, respectively).

Concentrations of terbuthylazine peaked at $9.60 \mu \mathrm{g} \mathrm{L} \mathrm{L}^{-1}$ at W1 (Fig. 4a) on the day of herbicide application. By the end of the monitoring period on the day of herbicide application, concentrations had declined to $<3 \mu \mathrm{g} \mathrm{L} \mathrm{L}^{-1}$ and remained below this concentration for the remaining 5 months of the trial. Concentrations of terbuthylazine declined down the stream system (Fig. 4a), peaking at $2.5 \mu \mathrm{g} \mathrm{L}^{-1}$ at $\mathrm{W} 2$ on the day of herbicide application and remaining below $0.3 \mu \mathrm{g} \mathrm{L} \mathrm{L}^{-1}$ at W3 for the duration of the trial. The terbuthylazine metabolite terbuthylazine-desethyl was first recorded at W1 2 days after herbicide application and was present on all remaining sampling dates at concentrations of $<1 \mu \mathrm{g} \mathrm{L}{ }^{-1}$. Terbuthylazine-desethyl was evident at W2 from 1 week after herbicide application onwards, at concentrations of $<0.3 \mu \mathrm{g} \mathrm{L}^{-1}$, and was intermittently recorded at W3 from 1 month after herbicide application with concentrations close to, or below, detection limits.
Concentrations of hexazinone peaked at $5.30 \mu \mathrm{g} \mathrm{L}{ }^{-1}$ at W1 on the day of herbicide application, declining to $2.9 \mu \mathrm{g} \mathrm{L}^{-1}$ by the end of the monitoring period (Fig. 4b). After the day of herbicide application, concentrations ranged from 3.7 to $<1 \mu \mathrm{g} \mathrm{L}{ }^{-1}$ for the remainder of the monitoring period. Similar to terbuthylazine, concentrations of hexazinone declined downstream, measuring $2.1 \mu \mathrm{g} \mathrm{L}^{-1}$ on the day of herbicide application at W2 and declining thereafter (Fig. 4b). Hexazinone concentrations at $\mathrm{W} 3$ remained below $0.5 \mu \mathrm{g} \mathrm{L}^{-1}$ for the duration of the trial. The highest concentrations of terbuthylazine and hexazinone in stream water after the day of herbicide application were measured approximately 1 month (34 DAT) later at W1 (Fig. 4a, b). This value was recorded 2 days after the highest daily rainfall $(52 \mathrm{~mm})$ recorded after herbicide application (Fig. 2).

Data from W1 were used to calculate the amount of herbicide exported from this site in the first $24 \mathrm{~h}$ after herbicide application since the highest concentrations of herbicide in stream water were measured at this site on the day of herbicide application. Forty-two kilograms of terbuthylazine and $10.5 \mathrm{~kg}$ of hexazinone were applied to the land upstream of W1, and 0.003 and $0.005 \%$, respectively, were exported from the stream in the first $24 \mathrm{~h}$ after spraying.

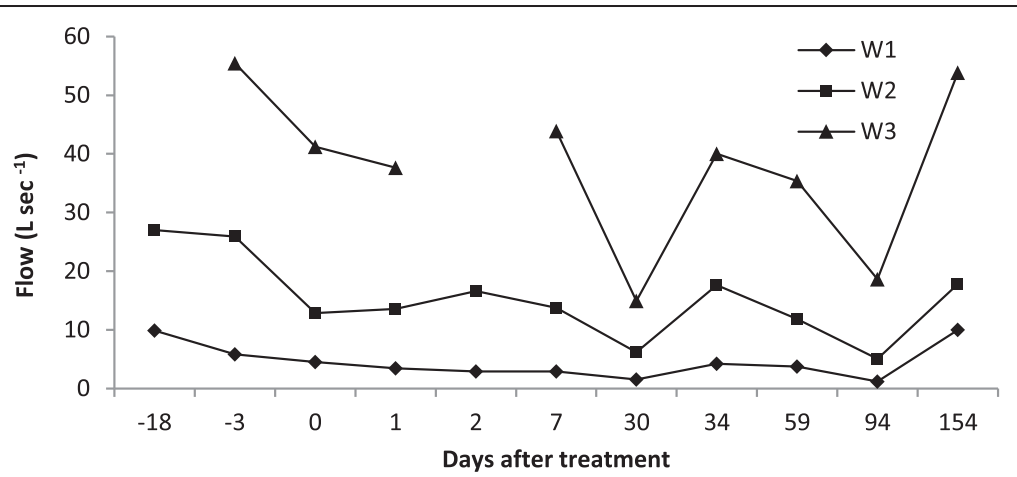

Fig. 3 Water flows measured at $W 1-W 3$ at the time of sampling 

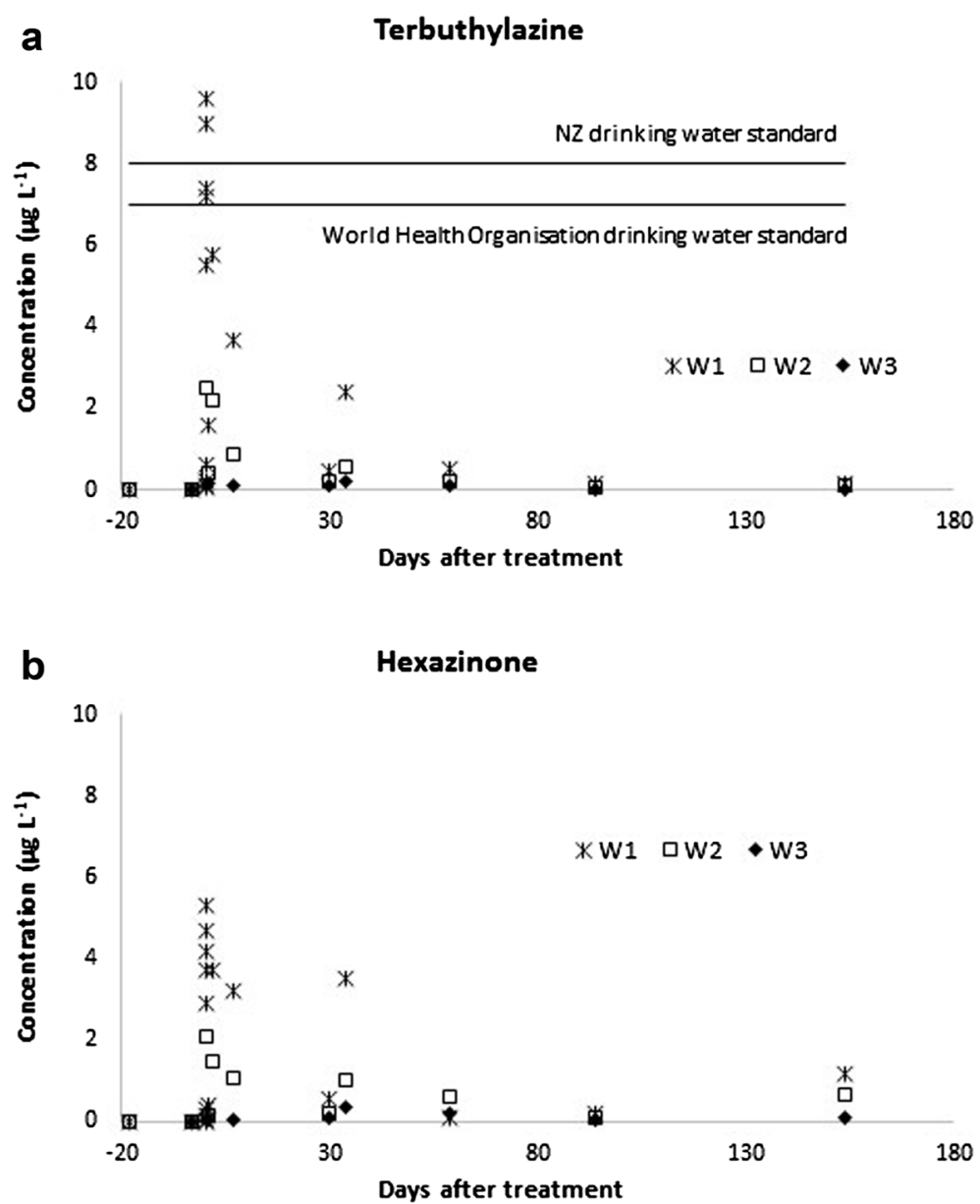

Fig. 4 Concentrations of terbuthylazine (a) and hexazinone (b) measured in stream water at W1 and the two downstream sites (W2 and W3) during the trial period. The acceptable limits for the New Zealand (NZ) and World Health Organization drinking water standards for terbuthylazine are shown in a. The NZ drinking water standard for hexazinone of $400 \mu \mathrm{g} \mathrm{L}{ }^{-1}$ is outside the range of $\mathbf{b}$. There is no World Health Organization drinking water standard for hexazinone

Terbuthylazine (33, 41 and $33 \mu \mathrm{g} \mathrm{kg}^{-1}$ ) was detected in sediment samples from W1 at 1, 30 and 59 DAT, respectively, but remained below detection limits for the remainder of the trial. No hexazinone was detected in sediment samples taken at W1 after herbicide application.

\section{Discussion}

Aerial application of terbuthylazine and hexazinone under operational conditions in a steepland catchment resulted in concentrations in the stream waters that were either similar to, or lower than, a previous study on New Zealand hill country Pumice Soil (Baillie et al., 2015). This was contrary to the hypothesis that aerial application of herbicides to steepland forests would pose a higher risk to the aquatic environment than on gentler slopes. One factor influencing these results was the $\approx 30$ $m$ 'no-spray' zone along either side of the stream channels in this catchment. The prescribed 10-m 'no-spray' zone in the Bay of Plenty study (Baillie et al., 2015) resulted in an average of 14 to $36 \%$ of the full application rate reaching the tracer plates along the stream channel, compared with an average of 0.4 to $27 \%$ of the full application rate reaching the stream channel in this trial. However, the high herbicide concentrations detected on the two sets of tracer plates in the upper stream catchment (average $27 \%$, and $10 \%$, of the full application rate) indicated that a buffer of this width had a limited effect on minimising spray drift into the stream channel under these operational conditions. An additional buffer would have been provided by the depth and extent of logging slash along the stream channel upstream of W1, further reducing the amount of herbicide reaching the stream channel. As a result of these factors, concentrations of both terbuthylazine and hexazinone in stream water were generally low for the duration of the trial. The exception was terbuthylazine concentrations at W1, which exceeded the WHO (World Health 
Organization 2011) and New Zealand drinking water standards (Ministry of Health, 2008) (Table 1) for 1 and $3 \mathrm{~h}$, respectively, on the day of herbicide application. Drinking water standards are based on the highest concentration considered not to cause a significant risk to the health of the consumer over an average lifetime (usually 70 years) based on a body weight of $60-70 \mathrm{~kg}$ and a daily consumption rate by an adult of $2 \mathrm{~L}$ of water per day (Ministry of Health, 2008; World Health Organization 2011). The time frame of exceedance for terbuthylazine in this trial was well below the decadal time threshold required to exceed drinking water standards. In addition, the remoteness of this site from public drinking water supplies indicated that the risk to human health from ingestion of water was likely to be very low.

The decline in herbicide concentrations downstream was a combined effect of the decreasing proportion of catchment area treated with herbicides, the dilution effect of increasing downstream distance and flow and, to a lesser extent, the influence of time since herbicide application on herbicide decay rates (as indicated by the presence of the terbuthylazine metabolite, terbuthylazine-desethyl). As a result, at the point where the stream exited the planted forest catchment (W3), concentrations of both herbicides were very low $\left(<0.5 \mu \mathrm{g} \mathrm{L}^{-1}\right)$. These finding were similar to other studies that have monitored herbicide concentrations downstream from the application site (Lavy et al., 1989; Neary et al., 1983).

The study by Baillie et al. (2015) and other studies (i.e. Lavy et al., 1989; Neary et al., 1983) have highlighted the risk of elevated herbicide concentrations from rainfall events occurring shortly after herbicide application. In this trial, elevated herbicide concentrations approximately 1 month (34 DAT) after herbicide application, which was 2 days after the highest daily rainfall event (52 mm) (Fig. 4a, b), indicated that herbicides were still being flushed from the system at least 1 month after herbicide application. There was a possible risk of leaching during this rainfall event that was sufficient to generate drainage in the soil profile in the catchment upslope of W1 (Garrett et al., 2016). This time frame was supported by results from a study by Lavy et al. (1989) where hexazinone was applied using spot spraying on a steepland catchment (slopes $\approx 40 \%\left(20^{\circ}\right)$ ) in West Virginia, USA, while retaining a 15-m 'no-spray' boundary along the stream margin. The highest concentration of hexazinone $\left(16 \mu \mathrm{g} \mathrm{L}^{-1}\right)$ was recorded in stream water during a $60-\mathrm{mm}$ rainfall event approximately 2 months (68 DAT) after herbicide application.

When compared with toxicology data (Table 1), the duration of detectable concentrations of both terbuthylazine and hexazinone recorded in this study (Fig. 4a, b) were below the levels required to pose a risk to algae and were several orders of magnitude lower than the toxicity $\left(\mathrm{LC}_{50}\right)$ levels for Daphnia spp. and rainbow trout (Oncorhynchus mykiss). These results indicate that terbuthylazine and hexazinone concentrations in this study did not exceed the regional rule requirement that 'discharge of agrichemical chemicals from aircraft must not result in any harmful concentration of agrichemical into water' (Bay of Plenty Regional Council, 2003).

Inherent in the hypothesis of a higher risk of herbicide contamination in steepland forest waterways was the potential for steep highly erodible sites such as the catchment in this study to convey herbicides to the stream via sediment transport off the hillsides, particularly terbuthylazine. Although terbuthylazine was detected in stream sediment at W1 for 2 months after herbicide application in this study, it persisted at higher concentrations and for a longer period in stream sediment in both year 1 and year 2 in a similar study conducted in the Bay of Plenty (Baillie et al., 2015). The lower initial concentrations of terbuthylazine reaching the stream water on the day of herbicide application at this site and the high herbicide terrestrial decay rates (a half-life of $<1$ day) (Garrett et al., 2016) are two potential contributing factors influencing these results.

As hexazinone is primarily transported in solution due to its high water solubility (Table 1 ), its low concentrations and residence time in sediment in the Bay of Plenty study (Baillie et al., 2015) and its non-detection in sediment sampled in this study are not surprising. However, Michael et al. (1999) did record a bi-model response of hexazinone in sediment, declining to around 180 DAT with a subsequent increase up to 360 DAT. The authors attributed this response to erosion and overland flow during storm events transporting and depositing terrestrial derived sediment, contaminated with the herbicide, into the stream channel. This is a potential risk in highly erodible steepland forests, particularly for terbuthylazine, but this process was not observed in this study possibly due to the shorter time frame (154 DAT) and insufficient rainfall events to transfer terrestrial sediment to the stream. The study on the terrestrial fate of terbuthylazine and hexazinone in the catchment upstream from W1 (Garrett et al., 2016) indicated that significant terbuthylazine contamination of in-stream sediment from terrestrial derived sources was unlikely beyond the first 2 weeks after herbicide application.

\section{Conclusions}

Although the potential risk of herbicide contamination of water ways is likely to be highest in steepland forests, this risk was minimised by the combined use of 'no-spray' zones along the stream channel, the buffering capacity of logging slash in the stream channel and the spatial distribution of treated areas within the catchment. Leaching 
did not appear to be an important process for off-site transfer of herbicides into waterways from forest environments, even in Pumice and Recent soils which have a high leaching potential. Any risk of leaching into waterways and the offsite movement of herbicides in waterways is likely to be highest during high rainfall events, particularly during the initial months after herbicide application. Given the rapid decline in herbicide concentrations over time and the downstream dilution effect on herbicide concentrations, under operational conditions, and when applied according to manufacturer's instructions, the downstream risk of these two herbicides to human health and aquatic organisms appeared to be low and was within regional rule requirements.

\section{Acknowledgements}

This research was funded by AgResearch through the Undermining Weeds programme (Contract C10X0811) with funding contribution towards field monitoring from the New Zealand Forest Growers Levy Trust. Rod Brownlie, Liam Wright and Tony Evanson provided technical support and assisted with the field data collection. Caroline Gous and Stefan Gous analysed the tracer plates, and Stefan Gous provided technical advice. Carol Rolando reviewed the draft manuscript and provided managerial support for the project. I would like to thank the two anonymous reviewers for their useful comments on the manuscript.

\section{Authors' contributions}

The author designed the project, was involved in the data collection along with technical assistance (see Acknowledgements), analysed the data and wrote the manuscript.

\section{Competing interests}

The author declares that she has no competing interests.

Received: 18 January 2016 Accepted: 28 July 2016

Published online: 01 September 2016

\section{References}

APHA. (2012). Standard methods for the examination of water and wastewater (22nd ed.). Washington DC: American Public Health Association, American Water Works Association, and the Water Environment Federation.

Baillie, B., \& Neary, D. (2015). Water quality in New Zealand's planted forests: a review. New Zealand Journal of Forestry Science, 45, 7.

Baillie, B. R., \& Rolando, C. A. (2015). Long-term management of streams in planted forest steeplands. New Zealand Journal of Forestry, 60(2), 21-24.

Baillie, B. R., Neary, D. G., Gous, S., \& Rolando, C. A. (2015). Aquatic fate of aerially applied hexazinone and terbuthylazine in a New Zealand planted forest. Journal of Sustainable Watershed Science \& Management, 2(1), 118-129. doi: 10.5147/jswsm.2015.0187.

Barbash, J. E., \& Resk, E. A. (1996). Pesticides in ground waters: distribution, trends, and governing factors. No 2 (Pesticides in the hydrologic system). MI, United States of America: Ann Arbor Press Inc.

Bay of Plenty Regional Council (2003). Bay of Plenty Regional Council Air Plan. Environmental publication 2003/22, updated 2006. Whakatane, New Zealand: Bay of Plenty Regional Council.

Beek, B., Böhling, S. Bruckmann, U., Franke, C., Jöhncke, U., \& Studinger, G. (2000). The assessment of bioaccumulation. In B. Beek (Ed.), The handbook of environmental chemistry (Part J Bioaccumulation, Vol. 2, pp. 235-276). Berlin Heidelberg: Springer-Verlag.

Chappell, P. R. (2013). The climate and weather of the Bay of Plenty - 3rd edition (NIWA Science and Technology Series Number 62). Wellington, New Zealand: National Institute of Water and Atmospheric Research (NIWA).

Close, M. E., \& Skinner, A. (2012). Sixth national survey of pesticides in groundwater in New Zealand. New Zealand Journal of Marine and Freshwater Research, 46(4), 443-457.

Dunningham, A., Kirschbaum, M., Payn, T., \& Meason, D. (2012). Chapter 7. Forestry: long-term adaptation of productive forests in a changing climatic environment. In A. Clark \& R. Nottage (Eds.), Impacts of climate change on land-based sectors and adaptation options. Technical Report to the Sustainable Land Management and Climate Change Adaptation Technical Working Group. MPI Technical Paper No: 2012/33 (pp. 293-346). Wellington, New Zealand: Ministry for Primary Industries.

Forest Owners Association \& Ministry for Primary Industries. (2013). New Zealand plantation forest industry facts \& figures 2012/2013. Wellington, New Zealand: Forest Owners Association and Ministry for Primary Industries.

Forest Stewardship Council. (2005). FSC Pesticides Policy FSC-POL-30-001. Bonn, Germany: Forest Stewardship Council Policy and Standard Unit, FSC International Center.

Garrett, LG, Watt, MS, \& Pearce, SH (2016). Environmental fate of terbuthylazine and hexazinone in a planted forest steepland Recent Soil, New Zealand. New Zealand Journal of Forestry Science, 46, 17.

Garrett, L. G., Watt, M. S., Rolando, C. A., \& Pearce, S. H. (2015). Environmental fate of terbuthylazine and hexazinone in a New Zealand planted forest Pumice soil. Forest Ecology and Management, 337, 67-76.

Hewitt, A. E. (1998). New Zealand soil classification (Landcare Research Science Series No. 1). Lincoln, New Zealand: Manaaki Whenua Press, Landcare Research Ltd.

Kronvang, B., Iversen, H. L., Vejrup, K., Mogensen, B. B., Hansen, A.-M., \& Hansen, L. B. (2003). Pesticides in streams and subsurface drainage water within two arable catchments in Denmark. Pesticide application, concentration, transport and fate (Danish Environmental Protection Agency. Pesticide Research, No. 69).

Larson, S. J., Capel, P. D., \& Majewski, M. (1997). Pesticides in surface waters: distribution, trends, and governing factors. No 3 (Pesticides in the hydrologic system, Vol. 3). MI, United States of America: Ann Arbor Press Inc.

Lavy, T. L., Mattice, J. D., \& Kochender, J. N. (1989). Hexazinone persistence and mobility of a steep forested watershed. Journal of Environmental Quality, 18 $507-514$

Little, K. M., Willoughby, I., Wagner, R. G., Adams, P., Frochot, H., Gava, J., Gous, S., Lautenschlager, R. A., Örlander, G., Sankaran, K. V., \& Wei, R. P. (2006). Towards reduced herbicide use in forest vegetation management. Southern African Forestry Journal, 207(1), 63-79. doi:10.2989/10295920609505254.

MacBean, C. (2012). The pesticide manual: a world compendium (16th ed.) Hampshire, UK: British Crop Production Council.

McBroom, M. W., Louch, J., Beasley, S. R., Chang, M., \& Ice, G. G. (2013). Runoff of silvicultural herbicides applied using best management practices. Forest Science, 59(2), 197-210.

McCarthy, N., Bensten, N. S., Willoughby, I., \& Balandier, P. (2011). The state of forest vegetation management in Europe in the 21st century. European Journal of Forest Research, 130(1), 7-16.

Michael, J. L., Webber, C. E., Bayne, D., Jr, R., Fischer, J. B., Gibbs, H. L., \& Seesock, W. C. (1999). Hexazinone dissipation in forest ecosystems and impacts on aquatic communities. Canadian Journal of Forest Research, $29,1170-1181$

Miller, J. H., \& Bace, A. C. (1980). Streamwater contamination after aerial application of a pelletized herbicide (Research Note SO-225). New Orleans, USA: USDA Forest Service.

Ministry of Health (2008). Drinking-water standards for New Zealand 2005 (Revised 2008). Wellington, New Zealand

Ministry of Works and Development (Cartographer). (1975). New Zealand Land Resource Inventory Worksheet Omaio N70.

Neary, D. G., \& Michael, J. L. (1996). Herbicides-protecting long-term sustainability and water quality in forest ecosystems. New Zealand Journal of Forestry Science, 26(1/2), 241-264.

Neary, D. G., Bush, P. B., \& Douglass, J. E. (1983). Off-site movement of hexazinone in stormflow and baseflow from forest watersheds. Weed Science, 31, 543-551.

NIWA. (2012). National Institute of Water and Atmospheric Research (NIWA). National and regional climate maps, Retrieved 22 May 2014: https:/www. niwa.co.nz/climate/research-projects/national-and-regional-climate-maps.

Pergher, G. (2001). Recovery rate of tracer dyes used for spray deposit assessment. Transactions of the American Society of Agricultural Engineers, 44(4), 787-794

Richardson, B. (1993). Vegetation management practices in plantation forests of Australia and New Zealand. Canadian Journal of Forest Research, 23, 1989-2005.

Richardson, B., Ray, J. W., \& Vanner, A. (1989). Evaluation of techniques to measure aerial spray deposition. New Zealand Plant Protection Proceedings of a conference Hastings New Zealand, 42, 132-136. 
Rolando, C. A., Garrett, L. G., Baillie, B. R., \& Watt, M. S. (2013). A survey of herbicide use and a review of environmental fate in New Zealand planted forests. New Zealand Journal of Forestry Science, 43, 17.

Roos, A. H., van Munsteren, A. J., Nab, F. M.. \& Tuinstra, L. G. M. (1987). Universal extraction/clean-up procedure for screening of pesticides by extraction with ethyl acetate and size exclusion chromatography. Analytica Chimica Acta, 196, 95-102.

Shepard, J. P., Creighton, J., \& Duzan, H. (2004). Forestry herbicides in the United States: an overview. Wildlife Society Bulletin, 32(4), 1020-1027.

Thiffault, N., \& Roy, V. (2011). Living without herbicides in Québec (Canada): historical context, current strategy, research and challenges in forest vegetation management. European Journal of Forest Research, 130(1), 117-133.

Tran, H., Harrington, K. C., Robertson, A. W., \& Watt, M. S. (2015). Relative persistence of commonly used forestry herbicides for preventing the establishment of broom (Cytisus scoparius) seedlings in New Zealand plantations. New Zealand Journal of Forest Science, 45, 6.

Tulagi, A. (2014). Waikato River water quality monitoring programme: data report 2013 (Waikato Regional Council Technical Report 2014/31). Hamilton, New Zealand: Waikato Regional Council.

University of Hertfordshire (2015). Pesticide Properties DataBase. Retrieved 27 Nov 2015: http://sitem.herts.ac.uk/aeru/ppdb/en/index.htm

Vörösmarty, C. J., Mclntyre, P. B., Gessner, M. O., Dudgeon, D., Prusevich, A., Green, P., Glidden, S., Bunn, S. E., Sullivan, C. A., Liermann, C. R., \& Davies, P. M. (2010). Global threats to human water security and river biodiversity. Nature, $467,555-561$

Wagner, R. G., Flynn, J., \& Gregory, R. (1998). Public perceptions of risk and acceptability of forest vegetation management alternatives in Ontario. The Forestry Chronicle, 74(5), 720-727.

Wagner, R. G., Little, K. M., Richardson, B., \& McNabb, K. (2006). The role of vegetation management for enhancing productivity of the world's forests. Forestry, 79(1), 57-79.

Watt, M. S., Wang, H., Rolando, C. A., Zaayman, M., \& Martin, K. (2010). Adsorption of the herbicide terbuthylazine across a range of New Zealand forestry soils. Canadian Journal of Forest Research, 40, 1448-1457.

World Health Organization (2010). The WHO recommended classification of pesticides by hazard and guidelines to classification 2009. Geneva, Switzerland.

World Health Organization (2011). Guidelines for drinking-water quality: fourth edition. Geneva, Switzerland.

\section{Submit your manuscript to a SpringerOpen ${ }^{\circ}$ journal and benefit from:}

- Convenient online submission

- Rigorous peer review

- Immediate publication on acceptance

- Open access: articles freely available online

- High visibility within the field

- Retaining the copyright to your article

Submit your next manuscript at $\gg$ springeropen.com 